\title{
MECHANISMS OF BIOLOGICAL PROCESSES IN DOMESTIC WASTEWATER TREATMENT PLANTS
}

\author{
Sylwia MYSZOGRAJ ${ }^{1}$ \\ University of Zielona Góra, Poland
}

\begin{abstract}
The growing demand for solutions of household sewage treatment plants means that many new or improved technological solutions are available on the market. The implementation of these technologies is associated with the need to known the mechanisms of the unitary biological processes occurring when removing organic carbon, nitrogen and phosphorus from wastewater. Determining the optimal conditions for these processes will determine the correct operation of the household sewage treatment plant.
\end{abstract}

Keywords: wastewater, organic carbon, nitrogen, phosphorus, biochemical processes

\section{INTRODUCTION}

Owners of real estates located in areas without a sewage network must ensure a system of efficient sewage management. Such a situation most often appears in locations of a dispersed building type, where the construction of a collective sewage system is unprofitable. A common problem of home owners in nonurbanized areas are also terrain conditions that do not allow for the establishment of a sewage system. One of the solutions to this problem is the possibility of sewage treatment in individual household sewage treatment plants. Low-cost, simple, efficient and reliable solutions are necessary. The method of removing pollution in a household sewage treatment plant is determined by the

\footnotetext{
${ }^{1}$ Corresponding author: University of Zielona Gora, Institute of Environmental Engineering, Szafrana st 15, 65-246 Zielona Góra, tel. +48683282574, e-mail: s.myszograj@iis.uz.zgora.pl
} 
amount and composition of the sewage generated in the household, local ground and water conditions, the size of the plot on which the treatment plant is to be located, as well as investment and operating costs, which largely determine the solution choice. The first element of every household sewage treatment plant should be a septic tank, because it ensures the elimination of the largest pollutants that are removed from sewage as a result of sedimentation, flotation and fermentation. In the next stage, regardless of the solution adopted, further treatment of sewage is carried out in biological processes [1]. In Poland, several types of household wastewater treatment plants are operated: sewage treatment plants with drainage and sand filter, constructed wetlands, systems with activated sludge and biofilters technology.

\section{BASIC SOLUTIONS FOR BIOLOGICAL DOMESTIC WASTEWATER TREATMENT}

\section{Constructed wetlands}

Constructed wetlands are a mapping of natural hydraulic conditions and habitat boggy ecosystems. In the environment, such a system is for most of the year a naturally marshy area, where the constant saturation with water causes the development of characteristic swampy and hydrophyte plants (hydrophytes). The hydrophyte method of sewage treatment is a biological process taking place with the participation of heterotrophic microorganisms existing in specially designed and made reservoirs - plant filters constituting the main element of the sewage treatment plant [2]. The hydrophyte method of sewage treatment consists in the simultaneous use of sorption processes, chemical reactions, ion exchange, sedimentation and evapotranspiration as well as the biological activity of macrophyte plants and microorganisms, which consists in bioaccumulation and biodegradation of organic and biogenic compounds. The main processes that enable effective nitrogen removal in soil and vegetable systems are nitrification and denitrification. A much smaller role in its elimination is played by the processes of oxidation, adsorption by the material filling the bed and its collection by plants. Phosphorus is mainly subject to the processes of cumulation, sorption and precipitation. The specific conditions prevailing in the filter favour the development of hydrophytes by intensifying the processes of oxidation and reduction of pollutants, which are supported by the sorption, sedimentation and assimilation processes taking place [3,4]. For the filtering of plant treatment plants: common reed, truncate cane, iris, manna mielec [Glyceria maxima]. Due to the extensive system of rhizomes and roots and high resistance to frosts and heat, the common reed is most commonly used. Oxygen from the 
atmospheric air flowing into the underground parts, through the porous gas tissue developed in the stems and leaves of the reed, forms around the rhizomes local oxygen zones, surrounded by hypoxic micro-zones, followed by reduction micro-zones. As a result, appropriate conditions are created enabling the development of organisms involved in biochemical transformations of incoming pollutants $[3,4]$.

\section{Sewage treatment plants operating in the technology of activated sludge}

The term "activated sludge technology" is defined as a set of biochemical processes in which the active elements are symbiotic or synergistic microorganisms, organized in zooglealne clusters - "flocs". They have a large active surface and are capable of biosorption of organic and inorganic substances found in sewage in dissolved and colloidal form. In the microscopic analysis, the flocs are usually visible as particles with a diameter of 50 to $100 \mu \mathrm{m}$. The active sludge flock is a minireactor placed in an aqueous environment (polyhydroxymastic acid solution) that has the characteristics of polyelectrolyte. Organic mass of activated sludge lumps, except carbon, hydrogen and oxygen, also includes: $8 \%$ nitrogen and $1 \%$ phosphorus. It is assumed that the organic substance has a total formula: $\mathrm{C}_{118} \mathrm{H}_{170} \mathrm{O}_{51} \mathrm{~N}_{17} \mathrm{P}$ [5]. In order to simplify calculations, biomass composition is expressed using simplified formulas, omitting phosphorus in the form $\mathrm{C}_{7} \mathrm{H}_{11} \mathrm{O}_{3} \mathrm{~N}$ or $\mathrm{C}_{5} \mathrm{H}_{7} \mathrm{O}_{2} \mathrm{~N}$ [5]. It should be emphasized that these formulas do not reflect the structural structure of microbial cells, but only express in which ratio of the molecules in the molecule there are macroelements that create them. The share of individual groups of microorganisms in bacterial culture depends on the conditions prevailing in the activated sludge chamber. In the activated sludge process nitrogen compounds are removed in the processes of ammonification, nitrification, denitrification and assimilation. Phosphorus is mainly subject to processes of assimilation, sorption and chemical precipitation.

\section{Biofilters}

Biofilters are devices for oxygen biochemical decomposition of organic pollutants contained in sewage. The main element of the biofilters is the filling on the surface the biological membrane, consisting of a number of microorganisms, mainly bacteria, develops. Sewage treatment using biofilters takes place in several stages. In the first stage sorption of organic pollutants contained in sewage on the surface of the biological membrane is carried out, in the second stage the use of impurities by microorganisms inhabiting the membrane. This is accompanied by the increase in biomass and removal of pollutants from sewage (sewage flow along the surface of the biological 
membrane causes mechanical peeling of its excess from the surface of the material filling the bed). In the final stage of sewage treatment, the biological membrane is separated from treated sewage as a result of sedimentation in the secondary sludge tank. Similarly to the process of activated sludge, nitrogen compounds are removed in assimilation, ammonification, nitrification and denitrification processes. Phosphorus is mainly subject to assimilation processes $[3,6]$.

\section{PROCESSES IN BIOLOGICAL WASTEWATER TREATMENT}

The simplified stoichiometric model of the biological sewage treatment process can be saved in the form of equations:

\begin{tabular}{|c|c|}
\hline $\begin{array}{l}\text { Oxidation of organic } \\
\text { carbon compounds }\end{array}$ & $\mathrm{C}_{\text {org }}+\mathrm{O}_{2} \stackrel{\text { heterortophs }}{\longrightarrow} \mathrm{CO}_{2}+\Delta($ heterotrophs $)+$ energy \\
\hline Ammonification & $N_{\text {org }}\left\langle N^{3-}\right\rangle \stackrel{\text { heterotrophs }}{\longrightarrow} \mathrm{NH}_{4}^{+}{ }^{\left\langle N^{3-}\right\rangle}$ \\
\hline Nitrification & $\begin{array}{l}\mathrm{NH}_{4}^{+\left\langle N^{3}\right\rangle}+\mathrm{O}_{2} \stackrel{\text { Nitrosomonas }}{\longrightarrow} \mathrm{NO}_{2}^{-\left\langle N^{s+}\right\rangle}+\Delta(\text { (autotrophs })+\text { energy } \\
\mathrm{NO}_{2}^{-\left\langle N^{3+}\right\rangle}+\mathrm{O}_{2} \stackrel{\text { Nitrobacter }}{\longrightarrow} \mathrm{NO}_{3}^{-\left\langle N^{s}\right\rangle}+\Delta(\text { autotrophs })+\text { energy }\end{array}$ \\
\hline Denitryfication & $\mathrm{NO}_{3}^{-\left\langle\mathrm{N}^{\mathrm{s}\rangle}\right\rangle}+\mathrm{C}_{\text {org }} \stackrel{\text { hecterorophs }}{\longrightarrow} \mathrm{N}_{2}^{\left\langle\mathrm{N}^{0}\right\rangle}+\mathrm{CO}_{2}+\Delta($ heterotrophs $)+$ energy \\
\hline
\end{tabular}

\section{Oxidation of organic carbon compounds}

Organic compounds contained in sewage are oxidized by heterotrophic microorganisms using oxygen as an electron acceptor. In metabolic processes, microorganisms use food substrates as a source of energy (catabolism) and for the synthesis of cellular material (anabolism). Biochemical transformations of these substrates take place with the participation of enzymes - proteins, the majority of which contain active groups, so-called coenzymes [6,7]. Microorganisms produce enzymes inside cells (endoenzymes) or externally (exoenzymes). Most organic compounds, such as fats, carbohydrates, proteins, hydrocarbons and their derivatives, can be food for microbes. Bacteria can not directly assimilate polypeptides and polysaccharides containing more than 6-7 monomer units. These compounds must be hydrolysed so that they can be an assimilable source of carbon for microorganisms [7,8]. This reaction breaks down the chemical bonding of the substance and forms a new bond with the hydrogen or hydroxyl group of the water molecule. As a result of hydrolysis, polymeric compounds are transformed into monomers. 
The basic element combining all the changes occurring in various aerobic organisms is the Krebs cycle (Citric acid cycle) (Fig.1) [9]. This cycle is a path providing energy to organisms under aerobic conditions. In the Krebs cycle, the transport of electrons to oxygen takes place via the respiratory chain with the simultaneous generation of ATP (adenosine triphosphate). In the Krebs cycle, enzymatic conversions occur, resulting in the separation of protons and the separation of carbon dioxide from the initial substrate (citrate), through intermediate products to the final product (oxaloacetate). A acetate particle with the participation of coenzyme $\mathrm{A}$ is attached to the oxaloacetate molecule and the starting citrate molecule is formed [10].

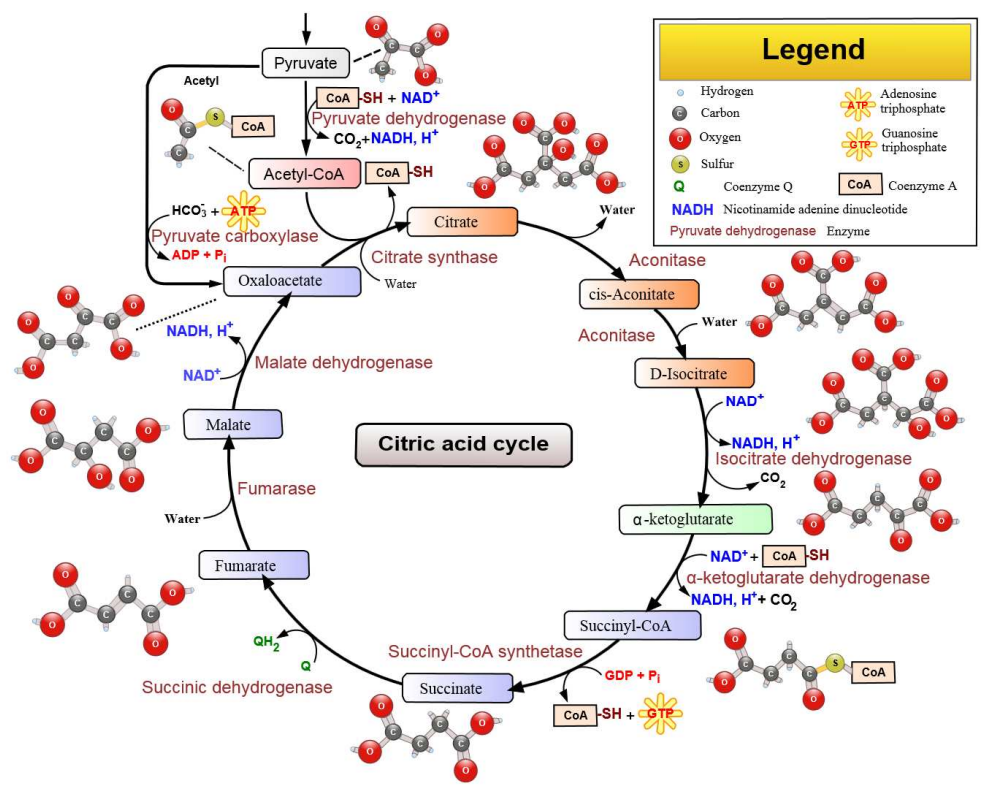

Fig. 1 Krebs cycle [9]

During the treatment of sewage in the soil or in the hydrophyte deposits, apart from the mineralization processes, the organic substances contained in the sewage are deposited to form humic compounds. The permeability of soils does not change as a result of the build-up of humus, but it causes an increase in the efficiency of removing pollutants. There is no time restriction on the exploitation of the systems in question due to the decomposition of organic particles or nitrogen compounds. Plant growth and the overgrowing of the soil with their rhizomes and roots basically guarantees sufficient hydraulic conditions even after many years, provided that the bed is made of incompressible, permeable 
material. The simultaneous occurrence of different unit processes of eliminating contaminations without organized oxygen supply may, however, lead to colmatization as well as to the accumulation of silt and organic material in the filter bed [11].

During long-term use, impurities are removed by transformation, filtration and sorption as well as by precipitation reactions. In various objects, contaminants are collected either near the inflow, in individual layers of the filter bed or evenly throughout the deposit. A significant degree of contamination of filtration material was found in root systems, while in sand-gravel beds of constructed wetlands, no significant accumulation of pollutants was found during the 15 years of operation. The highest content of impurities was observed at the places of inflow of substances, which are removed by filtration and in places where, as a result of biomass death, humus was formed [12].

Humus is an amorphous complex of numerous organic compounds differing in structure and physico-chemical properties, and resistant to biochemical degradation processes. This complex has not yet been properly studied, although it is known that it is created as a result of humification, and includes, among others, humic and ulmic acids, fulvic acids, hymatomelic acid, and ulmines and humines, which are complexes of polycyclic aromatic connections and condensation derivatives of phenol, sugars, amino acids and proteins.

Caries compounds regulate the water balance of soils, as humus has enormous water absorbing capacity ( $4 \div 40$ times compared to its own weight), however, this feature is reversible. Absorbing water, humus swells and expands, giving up water reduces its volume. This constant decompression and shrinkage of the caries favorably affects the loosening of the soil structure, which facilitates the access of air and water to the soil. Carious colloids have enormous sorption, buffering and high enzymatic activity [12].

\section{Ammonification}

Ammonification is the decomposition of nitrogen compounds under the influence of microorganisms, leading to the formation of ammonia or ammonium salts. Ammonification occurs in both aerobic and anaerobic conditions - it does not require the participation of oxygen $[3,8,13]$. The proteins, nucleic acids, urea and uric acid, which are quickly ammoniticized according to the reaction:

$\mathrm{C}_{10} \mathrm{H}_{19} \mathrm{O}_{3} \mathrm{~N}+12,5 \mathrm{O}_{2} \rightarrow 9 \mathrm{CO}_{2}+7 \mathrm{H}_{2} \mathrm{O}+\mathrm{NH}_{4} \mathrm{HCO}_{3}$

\section{Nitrification}

Nitrifying bacteria are absolute, aerobic chemo-lithium-autotrophic organisms. They oxidize ammonium compounds to nitrites, and then to nitrates only when 
they have oxygen as an acceptor of electrons. As a result of electron transfer to oxygen, the energy used for protein synthesis (chemotrophy) is released. The building material for protein synthesis is inorganic substances, in particular carbon dioxide and ammonium compounds (autotrophy). Because the energy gain from ammonium oxidation is small, nitritans are forced to process large amounts of electron donors to carry out cell division processes. The speed of reproduction is therefore small, but the processing speed is very high (Fig.2). This means that even with fewer nitrite populations, high nitrification efficiency can be achieved $[3,8,13]$.

The main species responsible for the nitrification process are $[3,8]$ :

a) oxidizing bacteria $\mathrm{N}-\mathrm{NH}_{4}{ }^{+}$to $\mathrm{N}-\mathrm{NO}_{2}{ }^{-}$:

They include the following: Nitrosomonas, sticks $(1.0 \times 1.5 \mu \mathrm{m})$ equipped with a polar cilia; Nitrosococcus, cocci $(1.8 \times 2.2 \mu \mathrm{m})$, Nitrosolobus, pleomorphic, mobile cells $(1-2.5 \times 1-2.5 \mu \mathrm{m})$, often with intracellular, membranous compartments; Nitrosospira, spirally twisted sticks; and Nitrosovibrio, small curved sticks.

b) oxidizing bacteria $\mathrm{N}^{-\mathrm{NO}_{2}}{ }^{-}$to $\mathrm{N}-\mathrm{NO}_{3}{ }^{-}$:

They include the following: Nitrobacter, in terms of morphology similar to Nitrosomonas, only slightly smaller $(0.8 \times 1.4 \mu \mathrm{m})$, Nitrococcus, granuloma $(1.5$ $\times 1.8 \mu \mathrm{m})$, Nitrospine $(0.3-0.4 \times 2,7-6,5 \mu \mathrm{m})$. Nitrobacter and Nitrococcus contain membranous structures, differently distributed inside the cytoplasm. They are relative autotrophs capable of heterotrophic growth. The yield of chemosynthesis ranges from 2 to $11 \%$.

Nitrification is carried out in two steps by reaction [13]:

\section{Stage I:}

Oxidation of ammonium nitrogen to nitrite with the participation of Nitrosomonas bacteria; Nitrosocystis, Nitrosolobus, Nitrosospira also take part in this phase:

$$
\begin{aligned}
& 80,7 \mathrm{NH}_{4}^{+}+114,55 \mathrm{O}_{2}+160,4 \mathrm{HCO}_{3}^{-} \stackrel{\text { Nitrosomonas }}{\longrightarrow} \\
& \qquad \mathrm{C}_{5} \mathrm{H}_{7} \mathrm{O}_{2} \mathrm{~N}+79,7 \mathrm{NO}_{2}^{-}+82,7 \mathrm{H}_{2} \mathrm{O}+155,4 \mathrm{H}_{2} \mathrm{CO}_{3}
\end{aligned}
$$

\section{Stage II:}

Oxidation of nitrites to nitrates with the participation of mainly Nitrobacter bacteria, to a lesser extent Nitrococus and Nitrospina:

$$
\begin{array}{r}
134,5 \mathrm{NO}_{2}^{-}+\mathrm{NH}_{4}^{+}+\mathrm{HCO}_{3}^{-}+62,25 \mathrm{O}_{2}+4 \mathrm{H}_{2} \mathrm{CO}_{3} \stackrel{\text { Nitrobacter }}{\longrightarrow} \\
\mathrm{C}_{5} \mathrm{H}_{7} \mathrm{O}_{2} \mathrm{~N}+3 \mathrm{H}_{2} \mathrm{O}+134,5 \mathrm{NO}_{3}^{-}
\end{array}
$$



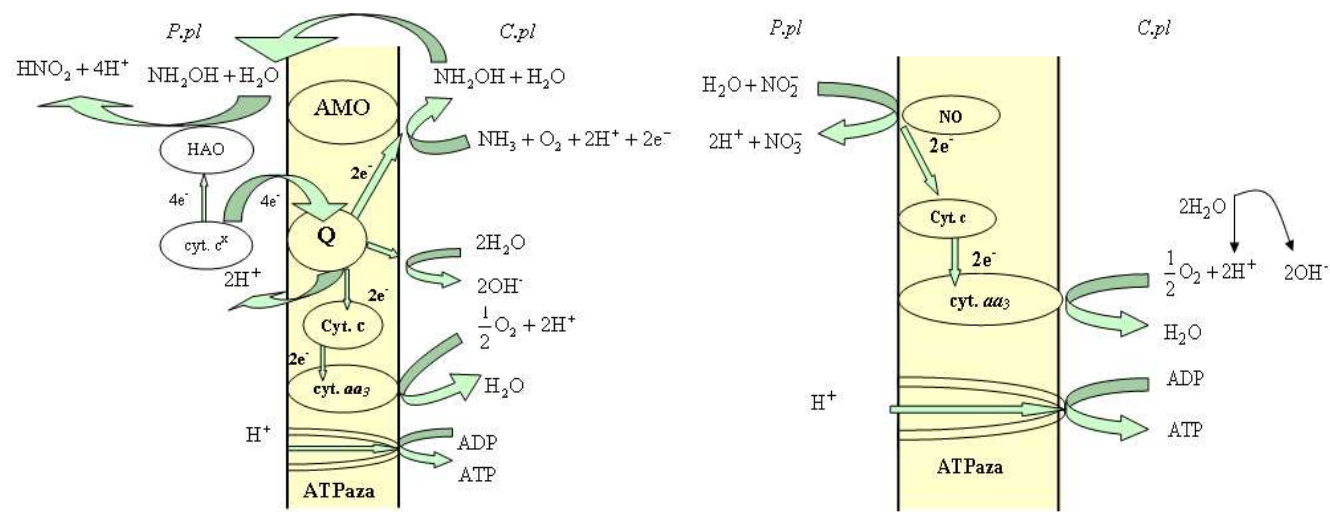

Fig. 2 The mechanism of the nitrification process

a) ammonia oxidation: Q - quinone cx cyt - a specific cytochrome, different from cytochrome c; HAO - hydroxylamine oxidoreductase; AMO - ammonia monoxygenase.

b) nitrite oxidation: NO - nitrite oxidoreductase, ATPase - proton pump; P.pl - periplasm, C.pl - cytoplasm, ADP-desisodiphosphosphate, ATP - adenosinphosphate.

From equations (7-8) the following conclusions arise:

1. The nitrification process is associated with significant oxygen consumption. Oxidation every gram of $\mathrm{N}_{-} \mathrm{NH}_{4}{ }^{+}$into $\mathrm{N}^{-\mathrm{NO}_{2}}{ }^{-}$the need to $3.22 \mathrm{gO}_{2}$, and to

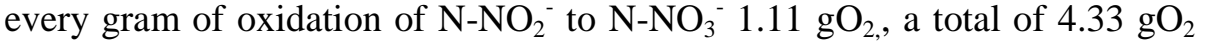
[13]. The actual oxygen demand is slightly higher and amounts to $4.57 \mathrm{gO}_{2} / \mathrm{g}$ $\mathrm{NH}_{4}{ }^{+}$. These differences are caused by the assimilation of nitrogen by microorganisms.

2. In the first stage of nitrification, large amounts of alkalinity are required to oxidize ammonium nitrogen, i.e. $8.64 \mathrm{gHCO}_{3}{ }^{-} / \mathrm{gN}-\mathrm{NH}_{4}$, only a small amount of carbon from bicarbonate is incorporated into the cell material, most of the bicarbonate is used to neutralize hydrogen ions;

3. As a result of the oxidation of 1 gram of ammonium nitrogen, only about 0.15 grams of dry biomass of Nitrosomonas bacteria is produced in the first stage and about 0.02 gram of dry biomass of Nitrobacter bacteria in the second stage of the nitrification process.

Necessary environmental conditions for the nitrification process:

- Nitrification does not occur at oxygen concentrations below from 0.2 to $0.5 \mathrm{gO}_{2} / \mathrm{m}^{3}$. To avoid the negative impact of dissolved oxygen deficiency, its concentration in the nitrification process should be maintained at a level of at least from 1.5 to $2.0 \mathrm{gO}_{2} / \mathrm{m}^{3}$. However, it was found that even a multi-hour lack of oxygen is not lethal for nitrites.

- The optimal $\mathrm{pH}$ is from 7.5 to 8.0. 
- The optimal process temperature is $25-28^{\circ} \mathrm{C}$. Above temperature $35^{\circ} \mathrm{C}$ the rate of growth of nitrites begins to decrease.

- The presence of carbon compounds promotes the development of heterotrophs that effectively compete with nitrifying bacteria for common substrates (ammonium nitrogen, oxygen) contributing to the speeding of nitrification [13].

\section{Denitrification}

Denitrification bacteria are widespread in nature. Denitrifiers are not so specialized bacteria as nitrites, hence they are active in many biochemical processes. In anaerobic conditions, they use nitrogen compounds as electron receptors. These bacteria are very diverse in terms of biochemistry and physiology. They belong to different systematic groups. They represent heterotrophic organisms. Most of them are Gram-negative rods, but other morphological types like Gram-positive bacilli, spherical and spiral forms are found. The denitrification process may, among others, lead to bacteria belonging to the genera: Alcaligenes (A. eutrophus, A. faecalis), Arthrobacter (A. citreus, A. simplex, A. terregnes), Bacillus (B. licheniformis, B. stearothermophilus), Chromobacterium (Ch. lividum, Ch. violaceum), Clostridium (C. limosum, C. oroticum, $C$. rectum), Corynebacterium (C. mycetoides), Cytophaga (C. johnsonae), Dactylosporangium (D. aurantiacum), Eubacterium (E. niritogrnes), Flavobacterium (F. capsulatum), Hyphomicrobium (H. Vulgare), Moraxella (M. kingi), Mycobacterium (M. intracellulare), Nocardia (N. otididis-caviarum), Paracoccus (P. denitrificans), Pseudomonas (P. aeruginosa, $P$. aureofaciens, $P$. fluorescens, $P$. stutzeri), Rhizobium (Rh. leguminosarum, Rh. japonicum), Thiobacillus (Th. denitrificans) $[3,8,13]$.

In the denitrification process, bacteria reduce nitrates to gaseous forms of nitrogen. Anaerobic respiration with the participation of an inorganic hydrogen acceptor (so-called nitrate respiration) can only take place in those bacteria that have a complicated electron transport system containing numerous cytochromes. Denitrification bacteria reduce nitrogen compounds if they are in anaerobic conditions and have sufficiently decomposed organic matter in sufficient quantities (simple carbohydrates and organic acids). They obtain energy in this way in sufficient quantity to conduct life processes [14].

In general, the denitrification process can be described by the equation:

$$
\mathrm{NO}_{3}^{-}+0,5 \mathrm{H}_{2} \mathrm{O} \rightarrow 0,5 \mathrm{~N}_{2}+2,5[\mathrm{O}]+\mathrm{OH}^{-}
$$


The condition for the proper course of biological denitrification is access to easily decomposed organic carbon. When methanol is used as its source, the stoichiometry of the process is as follows:

$$
6 \mathrm{NO}_{3}{ }^{-}+5 \mathrm{CH}_{3} \mathrm{OH} \rightarrow 3 \mathrm{~N}_{2}+5 \mathrm{CO}_{2}+7 \mathrm{H}_{2} \mathrm{O}+6 \mathrm{OH}^{-}
$$

The equation taking into account the process of cell synthesis takes the form of:

$$
\mathrm{NO}_{3}{ }^{-}+1,08 \mathrm{CH}_{3} \mathrm{OH}+0,24 \mathrm{H}_{2} \mathrm{CO}_{3} \rightarrow 0,06 \mathrm{C}_{5} \mathrm{H}_{7} \mathrm{O}_{2} \mathrm{~N}+0,47 \mathrm{~N}_{2}+1,68 \mathrm{H}_{2} \mathrm{O}+\mathrm{HCO}_{3}^{-}
$$

Equations (9-11) describe stoichiometric denitrification as a reduction of nitrates to gaseous nitrogen. However, this process is multistage, which can be recorded as follows:

$$
\begin{aligned}
& \mathrm{NO}_{3}{ }^{-} \longrightarrow \mathrm{NO}_{2}{ }^{-} \rightarrow ? \rightarrow \mathrm{N}_{2} \mathrm{O} \longrightarrow \mathrm{N}_{2} \\
& +5-------+3--------+1-------0
\end{aligned}
$$

In the first step (connection $2 \mathrm{e}^{-}$) followed by reduction of nitrates to nitrites. The enzyme responsible for the last stage of transformation, nitrous oxide reductase, reduces (again 2e ) nitrogen oxide (I) to molecular nitrogen. The course of the reduction of nitrite ions to nitric oxide (I) is still under discussion. Until now, according to the classical scheme, $\mathrm{H}_{2} \mathrm{~N}_{2} \mathrm{O}_{2}$ acid was used as the intermediate product. Currently, this assumption is departing from the study of two hypothetical routes: direct reduction of nitrites to nitric oxide (I) or with nitric oxide (II) as an intermediate of reduction $[8,14]$.

The enzymes that catalyze denitrification are the reductases responsible for transferring electrons and protons from the respiratory chain carriers to further oxidation-reduction systems. Coenzymes such as flavin and nicotinamide nucleotides, vitamin PP, cellular hemines and cytochrome oxidases cooperate with them. The individual stages of denitrification are catalyzed by enzymes: nitrate reductase $\mathrm{A}$, nitrite reductase $\mathrm{A}$, nitric oxide reductase, nitrous oxide reductase $[3,8,14]$.

Necessary environmental conditions for the denitrification process:

- Enzymes taking part in subsequent stages of the denitrification process (DNiR, $\mathrm{DN}_{2} \mathrm{OR}$ ) are very sensitive to the presence of oxygen and are repressed even at its trace amounts.

- The availability of electrons derived from organic compounds is one of the most important factors on which the activity of heterotrophic denitrifying bacteria depends. 
- Denitrification proceeds fastest at $20^{\circ} \mathrm{C}$. A further increase in temperature does not accelerate the process.

- The process runs at the optimum speed in an inert environment in the $\mathrm{pH}$ range 6.8-7.4.

- Many organic and inorganic compounds affect the intensity of the course and activity of the denitrification process. This is due to the high sensitivity of enzymes (reductases) to toxic substances, as well as their inhibitory effect on cell growth and the activity of enzymes involved in the overall metabolism [15].

Both nitrification and denitrification bacteria have much greater metabolic and physiological flexibility than previously thought. In principle, the following processes of nitrogen elimination can be distinguished from the concept of classic denitrification [15]:

a) heterotrophic nitrification - oxygen denitrification,

b) autotrophic nitrification - oxygen denitrification,

c) autotrophic nitrification - autotrophic denitrification.

\section{Dephosphatation}

Phosphorus during sewage treatment is assimilated by growing biomass, and then it is removed together with excess sludge. Effective biological removal of phosphorus is based on the intensification of the growth of microorganisms collecting and binding compounds of this element. This process requires the provision of alternating aerobic and anaerobic conditions, enabling the selection and development of specific microorganisms demonstrating the ability to store phosphorus compounds inside cells in amounts several times their normal physiological demand $[6,8]$.

Bacteria characterized by a high ability to accumulate phosphorus are mainly gram-negative kernels of the genus Acinetobacter calcoaceticus, sticks Pseudomonas sp, splits from the genus Moraxella, and strains Aeromonas. According to literature data these strains can accumulate phosphorus up to $25 \%$ of dry cell mass [9]. These bacteria are able to accumulate excessive amounts of phosphorus in the condensed form, which are polyphosphates. Polyphosphates are high-molecular biopolymers composed of several or several thousand phosphate residues that are connected by high-energy bonds into a chain. In bacterial cells, they occur in combinations with various metal ions such as potassium, magnesium and calcium $[6,8,10]$.

Under anaerobic conditions, bacteria undergo a so-called stressful situation [11]. These microorganisms are mostly oxygen-neutral and use oxygen as an electron acceptor, they can not use inorganic compounds such as nitrates or sulphates. 
Under conditions of oxygen deficit, bacteria break down polyphosphates, obtaining energy in the form of ATP (Fig.3). This process is possible due to the existence of an enzymatic apparatus allowing the use of energy released at the breaking of high-energy polyphosphate chains. Hydrophosphate polyphosphate chains generate orthophosphates. Thanks to the energy obtained, bacteria synthesise back-up materials, eg poly- $\beta$-hydroxybutyrate (PHB) from organic substrates such as acetates, propionates, butyrates, succinates or lactates contained in wastewater. These substrates are usually fermentation products and stimulate the development of suitable bacteria, therefore the process of phosphorus removal proceeds more efficiently and faster, if the sewage flowing into the system is rotten. The biosynthesis of spare substances (mainly PHB) takes place in an environment devoid of both oxygen and nitrates $[8,10,11,15]$.

Phosphorus is taken up by microorganisms under aerobic conditions in much larger quantities (so-called luxury uptake) than the amount of phosphorus isolated from cells in anaerobic conditions. Under these conditions an easily accessible carbon source is used for the growth and development of bacterial cells. Poly- $\beta$-hydroxybutyrate is broken down to produce energy for the growth of microorganisms. At the same time, microorganisms produce new molecules of polyphosphates from dissolved phosphorus, in which excess energy is accumulated, thanks to which the incorporation of polyphosphate chains into their cells eliminates phosphorus compounds from sewage. The sediment rich in phosphorus compounds is removed from the system [11,15, 17].

In aerobic conditions, the accumulation of polyphosphates can be represented in a simplified way using the equation:

$$
\begin{array}{r}
\mathrm{C}_{2} \mathrm{H}_{4} \mathrm{O}_{2}+0,16 \mathrm{NH}_{4}^{+}+1,2 \mathrm{O}_{2}+0,2 \mathrm{PO}_{4}^{-3} \rightarrow \\
\mathrm{O}, 16 \mathrm{C}_{5} \mathrm{H}_{7} \mathrm{NO}_{2}+1,2 \mathrm{CO}_{2}+0,2\left(\mathrm{HPO}_{3}\right)_{\mathrm{n}}+0,44 \mathrm{OH}^{-}+1,44 \mathrm{H}_{2} \mathrm{O}
\end{array}
$$

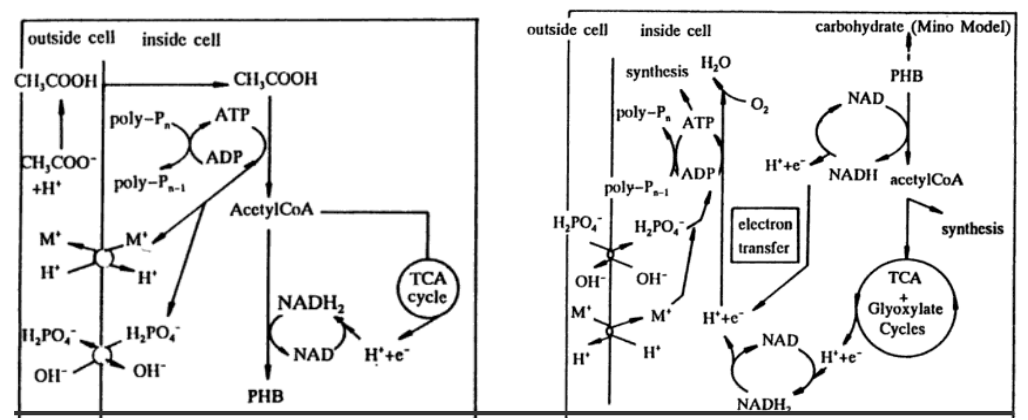

Fig. 3. Diagram of metabolic transformations of bacteria accumulating polyphosphates according to Comeau (anaerobic conditions - left, aerobic conditions - right) [17] 
The degree of removal of phosphorus by biological means depends primarily on the characteristics of sewage flowing into the biological reactor $\left(\mathrm{COD} / \mathrm{BOD}_{5}\right.$, $\mathrm{BOD}_{5} / \mathrm{P}, \quad \mathrm{COD} / \mathrm{P}, \quad \mathrm{VFA} / \mathrm{P}, \quad \mathrm{BOD}_{5} / \mathrm{N}$ ) and process conditions (nitrate concentrations in the anoxic zone), oxygen concentration in the aerobic zone, loading of activated sludge with organic matter, age of the sludge.

The quotient $\mathrm{BOD}_{5} / \mathrm{P}$ must be at least equal to 20 and $\mathrm{BOD}_{5} / \mathrm{N} \geq 20[7,15]$. The reaction has a very significant impact on the effectiveness of biological dephosphatation. The highest degree of removal of phosphorus from wastewater and the highest process stability ensures an increase in the $\mathrm{pH}$ of sewage to 8 . In addition, the excessively long residence time of sludge flocs in the aeration chamber can limit the secretion of phosphorus from the cells in the dephosphatation chamber, despite maintaining anaerobic conditions in it, which is explained by the flocculation of the flocs in the aerobic zone $[7,15,18]$.

If the value of the ratio $\mathrm{COD} / \mathrm{P}$ is less than 36 and the value of $\mathrm{COD} / \mathrm{BOD}_{5}$ is larger than 2 , it is reasonable to provide an additional anoxic zone easily degradable carbon. The most easily absorbed by the bacteria that remove phosphorus by carbon compounds are VFA, mainly acetates and propionates [18]. The high concentration of VFA in the anaerobic zone results in a faster growth of phosphorus bacteria, however, too high value of VFA in the anoxic and aerobic zones reduces the amount of phosphorus consumed. The consumption level in such conditions is close to zero. If there is an VFA in the anoxic/ aerobic zone that has not been completely used in the anaerobic zone, then phosphorus is released in these zones. The collection will take place when the volatile acids are removed [7,16].

The best ratio, VFA/P, is 5-6. According to Comeau [18], $7.5 \mathrm{mg}$ of acetic acid (corresponding to $8 \mathrm{mg}$ of easily decomposable COD) are used to remove $1 \mathrm{mg}$ of phosphorus from sewage. According to tests carried out under laboratory conditions in a three-phase system [anaerobic conditions - 2 hours, anoxic conditions (by adding $\mathrm{KNO}_{3}$ as a source of oxygen for bacteria) - 3 hours, aerobic conditions - 3 hours], the following conclusions can be drawn [18-20]:

- the efficiency of removing the total phosphorus for the value of VFA/P $=2.17$

- $33.15 \mathrm{mg} \mathrm{CH} \mathrm{CH}_{3} \mathrm{COOH} / \mathrm{mg} \mathrm{P}$ is high and amounts to $89.25-93.01 \%$. The concentration of total phosphorus in treated sewage was at the level of 0.72 $1.82 \mathrm{mgP} / \mathrm{l}$;

- rate and degree of release of orthophosphates under anaerobic conditions, and uptake under anoxic conditions increased with increasing VFA/P ratio in the range of $2.17-21.77 \mathrm{mg} \mathrm{CH} \mathrm{CHOOH}_{3} \mathrm{mg} \mathrm{P}$ and decreased with a higher VFA/P ratio; in aerobic conditions, the rate and rate of uptake of orthophosphates increased with the increase in VFA/P, but much lower than in anoxic conditions; 
- studies have shown that a significant amount of easily digestible carbon available in the anoxic zone causes further release of orthophosphate to sewage, while with small amounts of carbon, the uptake of orthophosphate starts already in the anaerobic zone.

In soil and wastewater treatment systems, phosphorus, present in the form of orthophosphates, polyphosphates and organic phosphorus, can be removed mainly due to the sorption process and its uptake by plants. Lantzke et al. [21] consider that the only mechanism for removing phosphorus in such plants is the cutting and harvesting of plants, but the amount of this element that can be removed in this way is small. Only about $10 \%$ of phosphorus and nitrogen is removed in this type of plant along with the collected biomass of plants. Phosphorus occurring in sewage in an inorganic form in soil-plant systems, can be largely retained in sorption and precipitation processes. The efficiency of these processes is determined mainly by the $\mathrm{pH}$ value and the oxidation-reducing potential and the presence of $\mathrm{Fe}^{3+}, \mathrm{Al}^{3+}$ or $\mathrm{Ca}^{2+}$ ions in the material used to eradicate the deposits, as well as depends on the amount of native phosphorus found in the material ejecting the deposit and the capacity sorption system $[2,18,19]$. In facilities where the material used to extinguish the bed is slightly acidic or neutral, the dominant role in sorption processes is attributed to iron and aluminum compounds, which sorb phosphor in the form of insoluble complex compounds, causing its long-term retention. However, in systems where alkaline materials are used, sorption processes of phosphorus may occur due to calcium compounds (eg calcium carbonates), with which phosphorus permanently forms mineral bonds $[19,21]$.

\section{CONCLUSIONS}

The processes of biological degradation of pollutants contained in the household and domestic sewage are dominated by processes taking place with the participation of microorganisms, as a result of which the organic substrates in catabolic reactions are decomposed to $\mathrm{CO}_{2}$ and $\mathrm{H}_{2} \mathrm{O}$. The removal of nitrogen and phosphorus is the result of complex biochemical reactions catalyzed by enzymes. In each case, the efficiency of sewage treatment depends mainly on the activity of microorganisms involved in the transformation. When describing the mechanisms of biooxidation of organic substances and the oxidation and reduction of nitrogen compounds, not only the necessary amount of oxygen in the system should be taken into account, the appropriate composition and concentration of substrates and the adapted microorganism cluster, but also the influence of the aquatic environment with its physico-chemical features, without whose course of complex biochemical changes is not possible. 


\section{REFERENCES}

1. Bârsan N., Nedeff V., Lazăr G.: Current stage of domestic wastewater treatment in small plants, Journal of Engineering Studies and Research, (2011), Vol. 17 No. 4

2. Vymazal J.: Horizontal sub-surface flow and hybrid constructed wetlands systems for wastewater treatment. Ecological Engineering, (2005) 25 (5), 478-490.

3. Myszograj S., Bydałek F.: Temperature impact of nitrogen transformation in technological system: vertical flow constructed wetland and polishing pond, Civil and Enviromental Engineering Reports, (2016), 23 (4), 125-136.

4. Myszograj S., Bydałek F., Płuciennik-Koropczuk E.: Evaluation of seasonal activity of various bacteria in a constructed wetland using AT4 and TTC tests, Desalination and Water Treatment, (2018), Vol. 134, 188-198.

5. Deublein D., Steinhauser A.: Biogas from waste and renewable resources. Wiley-VCH Verlag, 2008, ISBN 9783527318414.

6. Quansheng D., Qixing Ch., Zehui L., Shouwei Z.: Application of microbial technology in wastewater treatment. Progress in Applied Microbiology, (2017) https:// http://ojs.whioce.com/index.php/pam/article/download/534

7. Saad A. Al-Jlil, COD and BOD reduction of domestic wastewater using activated sludge, sand filters and activated carbon in Saudi Arabia. Biotechnology, (2009), 8, 473-477, DOI: 10.3923/biotech.2009.473.477

8. Sedlak R. I., Phosphorus and Nitrogen Removal from Municipal Wastewater: Principles and Practise, Lewis Publishers, 1991.

9. http://biocyc.org/META/NEW-IMAGE?type=PATHWAY\&object=TCA

10. Mino T.: Microbial selection of polyphosphate accumulating bacteria in activated sludge wastewater treatment process for enhanced biological phosphate removal. Biochemistry (Moscow), Vol. 65, No. 3, 2000, pp. 341348.

11. Kassab G., Halalsheh M., Klapwijk A., Fayyad M., Van Lier J.B.: Sequential anaerobic-aerobic treatment for domestic wastewater - A Review. Bioresource Technology, (2010) 101, 3299-3310.

12. Aiken G.R., Mcknight D. Wershaw. An introduction to humic substances in soil, sediments, and water. A Wiley-Interscience Publication, (1985).

13. Myszograj S.: The impact of temperature on the removal of nitrogen compounds in activated sludge system, British Journal of Applied Science \& Technology, (2015), Vol. 11, no. 1, 1-13.

14. Hochstein L.I., Tomlinson G.A., The enzymes associated with denitrification, Annual Review of Microbiology, (1988), DOI: 10.1146/annurev.mi.42.100188.001311. 
15. Kerrn-Jespersen J.P., Henze M.: Biological phosphorus uptake under anoxic and aerobic conditions. Water Research, (1993), Vol. 27 (4), 617-624.

16. Płuciennik-Koropczuk E., Myszograj S.: Zahn-Wellens test in industrial wastewater biodegradability assessment, Civil and Environmental Engineering Reports, (2018), 1 (28), 77-86; DOI: 10.2478/ceer-2018-0007.

17. Orhon D., Artan N.: Modelling of activated sludge systems, Tedchnomic Publishing Company, USA, 1994.

18. Comeau Y., Hall R., Hancock E.W., Oldham W.K.: Biochemical model for enhanced biological phosphorus removal, Water Research, (1986), Vol. 20 (12), 1511-1521.

19. Dacheng L., Linjiang Y., Lun L., Yang W., Wenwen F.: The mechanism of biological phosphorus removal under anoxic-aerobic alternation condition with starch as sole carbon source and its biochemical pathway, Biochemical Engineering Journal, (2018) Vol.132, 90-99.

20. Guerrero J., Albert Guisasola, Juan A. Baeza: The nature of the carbon source rules the competition between PAO and denitrifiers in systems for simultaneous biological nitrogen and phosphorus removal, Water Research, (2011) Vol. 45 (16), 4793-4802.

21. Lantzke I.R, Mitchell D.S, Heritage A.D, Sharma K.P.: A model of factors controlling orthophosphate removal in planted vertical flow wetlands, Ecological Engineering, (1999) vol.12, 93-105

\section{MECHANIZMY PROCESÓW BIOLOGICZNYCH W PRZYDOMOWYCH OCZYSZCZALNIACH ŚCIEKÓW}

\section{Streszczenie}

Rosnący popyt na rozwiązania oczyszczalni przydomowych spowodował, że na rynku dostępnych jest wiele nowych lub ulepszonych rozwiązań technologicznych. Wdrażanie tych technologii wiąże się z koniecznością poznania mechanizmów jednostkowych procesów biologicznych zachodzących podczas usuwania ze ścieków związków węgla organicznego, azotu i fosforu. Ustalenie optymalnych warunków prowadzenia tych procesów decydować będzie o poprawnej eksploatacji przydomowej oczyszczalni ścieków.

Słowa kluczowe: ścieki, węgiel organiczny, azot, fosfor, procesy biochemiczne 